\title{
Oposición política a la monarquía de Alfonso XIII. José Giral y los republicanos en la Dictadura de Primo de Rivera*
}

\section{Julián Chaves Palacios}

Universidad de Extremadura

RESUMEN: En este trabajo se ofrece una aproximación a los movimientos de oposición política a la monarquía durante la dictadura de Primo de Rivera, partiendo para ello de la consulta de una documentación inédita hasta ahora procedente del archivo personal del académico, político y farmacéutico José Giral Pereira. Éste, como activo republicano residente en la capital de España, ha dejado su testimonio personal sobre las actividades contrarias al régimen en las que participó en compañía de otros correligionarios. Y de acuerdo con su relato se van exponiendo esas maniobras desestabilizadoras, sus objetivos y desaciertos, asi como las vicisitudes que debieron afrontar los disidentes ante la sistemática persecución a la que se vieron sometidos por parte de las fuerzas del orden, que en su caso le originaron, entre otras contrariedades, ser encarcelado en varias ocasiones. Experiencias que se dan a conocer en todas sus interioridades, poniendo de manifiesto que fue en los últimos años de la dictadura cuando las actividades de oposición política adquirieron mayor relieve y cómo éstas, en directa relación con el quebranto sustancial sufrido por el sistema político monárquico, condujo a la población, especialmente en las grandes ciudades, hacia la República.

\section{Palabras clave: España; Monarquía; Dictadura; Oposición políti- ca; República.}

* Archivos consultados: AHN (Archivo Histórico Nacional). El contenido de este artículo se inserta en el Proyecto de Investigación número HAR2015-64814-P, aprobado en febrero de 2016 por el Ministerio de Economía y Competitividad, Plan Nacional Proyectos I+D. 
Political Opposition to Alphonse XIII's Monarchy. Jose Giral and the Republicans in the Dictatorship of Primo de Rivera

ABSTRACT: In this paper an approach to political movements opposed to the monarchy during the dictatorship of Primo de Rivera, starting this query to a hitherto unpublished documents from the personal archive of academic, political and pharmaceutical José Giral Pereira. This, as an active Republican residing in the capital of Spain, has left his personal testimony on anti-regime activities in which he participated in the company of other fellow. And according to the account, they will expose these destabilizing maneuvers, their objectives and mistakes and the vicissitudes the dissidents face against the systematic persecution to which they were subjected by the police that conducted, among other setbacks, to be imprisoned on several occasions. Experiences that are disclosed in all its internals, showing that it was in the last years of the dictatorship when political opposition activities acquired greater prominence and how they, in direct relation to the substantial grief suffered by the monarchical political system, led the population, especially in large cities, to the Republic.

KEY WORDS: Spain; Monarchy; Dictatorship; Political opposition; Republic.

\section{INTRODUCCIÓN}

La década de los años veinte del pasado siglo se caracterizó, en buena parte, por la implantación de la primera dictadura militar del novecientos hispano, un período en que la ejecutoria económica tuvo muchas más luces que sombras ${ }^{1}$. Evolución positiva de la economía que trajo consigo una estabilidad social sin precedentes en el país ${ }^{2}$, que sin embargo se fue deteriorando a medida que nos acercamos a los últimos años del septenato primorriverista. Objetivo de este estudio es profundizar en ese paulatino quebranto del régimen y, sobre todo, en el progresivo protagonismo que fueron adquiriendo los movimientos de oposición política republicanos pese a la implacable persecución de que fueron objeto sus seguidores.

Uno de éstos fue el académico y farmacéutico José Giral Pereira. A través de su peripecia vital en esos años, afortunadamente de público conocimiento tras el depósito de su archivo personal en un repositorio público ${ }^{3}$, hemos po-

1 TAMAMES, 2008: 313.

2 La dictadura se configura en diversos ámbitos de la vida nacional española del primer tercio de los años veinte como respuesta a una situación acusadamente conflictiva y deteriorada. GARCÍA DELGADO y JIMÉNEZ, 2001: 62.

$3 \mathrm{Su}$ contenido se encuentra depositado en el Archivo Histórico Nacional desde el año 2009, tras ser cedido en comodato por sus descendientes al Ministerio de Cultura de España. 
dido profundizar en los entresijos de esos movimientos de oposición, sus orígenes, contactos y acciones más representativas. Actividades ya difundidas, en líneas generales, por la bibliografía al uso, aunque necesitadas, en nuestra opinión, de una mayor concreción, de más detalles, objetivo para el que resulta imprescindible la información ofrecida por testigos que vivieron en primera línea esos hechos, como es el caso de este catedrático de universidad y político republicano. Sobre esas premisas se cimienta esta investigación que tiene en el testimonio de este personaje, tan poco tratado por la historiografía ${ }^{4}$, el principal soporte para profundizar en estos movimientos de oposición monárquica en la dictadura de los años treinta.

Y en ese sentido es necesario situar, en primer lugar, a Giral en el contexto de esos años para entender más adecuadamente su experiencia, señalando que arribó a la capital de España después de permanecer dieciséis años en Salamanca $^{5}$. Dejó esa ciudad tras solicitar la excedencia en su cátedra y comprar una farmacia en Madrid. En ello influyó la edad de sus hijos mayores que comenzaban a estudiar primaria en el Instituto-Escuela «y necesitábamos atenderlos». El traslado se produjo en abril de 1920, tras vender la farmacia de Salamanca por unos 10.000 duros. Esa cantidad, junto con los pequeños ahorros que tenía y el préstamo que le dio su suegra, le permitió comprar otra en Madrid «buena y acreditada», en la calle Atocha número 35 (en la actualidad 25), antigua calle Sánchez Ocaña, que le costó 22.000 duros al contado.

Añadió a esa inversión el laboratorio de análisis general que se trajo de Salamanca. Igualmente amplió y preparó en ella diversas especialidades y también el «sulfobarium» (preparado de sulfato de bario para radioscopia gastrointestinal). Mejoras que le permitieron aumentar las ventas: anualmente rendía un beneficio cercano a las 40.000 pesetas ( 8.000 duros), hasta el punto de convertirse en su núcleo principal de ingresos. Así describe Giral sus dependencias:

En el entresuelo de la casa (con comunicación interior desde la rebotica y exterior por la escalera del edificio) estaba mi despacho, el laboratorio de análisis y parte del almacén de medicamentos ${ }^{6}$

Una importante decisión que permite conocer el legado político, científico y cultural de este insigne republicano.

4 Destacamos en ese sentido la aportación, pese a no acceder al archivo personal de Giral ni mantener contacto con su familia, de PUERTO SARMIENTO, 2003; y un año después la obra sobre José Giral escrita por su hijo Francisco, en la que transmite los recuerdos sobre su progenitor. GIRAL, 2004; y sobre la realización de esas memorias por su hijo, véase EGIDO LEÓN, 2006: 105-122.

5 CHAVES PALACIOS, 32 (Valladolid, 2012): 195-216

6 Giral hacía estas manifestaciones en un texto escrito en 1944. A él nos referiremos a lo largo de este artículo cuando recojamos su testimonio personal acerca de sus vivencias. AHN, Sección Diversos José Giral (en adelante JG), Legajo n ${ }^{\circ} 8$. 
Ejerció de farmacéutico hasta enero de 1932 en que, ante la negativa de su hijo mayor a continuar con la farmacia, decidió venderla por el mismo precio que la adquirió en 19207. Igualmente precipitó la venta su designación, en octubre de 1931, como ministro de Marina del Gobierno presidido por Manuel Azaña y ser incompatible ese cargo con el ejercicio de otra actividad profesional.

\section{MAdRID Y EL RÉgIMen de PRIMo de RiVera: CONTROL POLÍTICO Y SOCIAL}

Pero hasta que eso sucedió lo cierto es que al año siguiente de estar residiendo en la capital de España, Giral fue nombrado jefe de la sección de Química del Instituto Español de Oceanografía ${ }^{8}$, que dirigía Odón de Buen a quien Giral había conocido a través de su hijo Demófilo de Buen, académico y compañero en la Universidad de Salamanca ${ }^{9}$. Desempeñó ese cargo durante una década (1921-1931) y a través de él pudo profundizar en la problemática de la marina nacional e internacional, participando en estudios científicos e interviniendo en reuniones oceanográficas ${ }^{10}$. Éstas generalmente eran en el extranjero a finales del verano y le solía acompañar su mujer, María Luisa, con la que cumplía una de sus pasiones: viajar. Al parecer llegaron a recorrer juntos casi toda Europa en esos años. De su actividad al frente de esta responsabilidad en el Instituto, P. Bosch afirma:

En el Instituto Giral se incorporó al grupo de pioneros integrado por Rafael y Fernando de Buen, Frutos A. Gila, Olimpio Gómez Ibáñez y J. Ferrer Hernández. Durante ese tiempo publicó trabajos de química oceanográfica discutiendo ante todo el concepto de agua normal. Le interesaron la materia orgánica y las algas del mar aunque también, como químico, hizo determinaciones de sulfatos, halógenos, oxígeno fosfatos y compuestos nitrogenados. Estudió los mucígenos y la algina con la idea de aprovecharlos para la alimentación o para extraerles el yodo $(\ldots)^{11}$.

Por tanto, su experiencia en ese cargo le permitió especializarse en contenidos marítimos, a los que trasladó sus conocimientos científicos en el estudio

7 Al parecer este hijo, Francisco, tras contraer matrimonio, en compañía de su mujer decidió marcharse a trabajar a Heidelberg.

8 PÉREZ-RUBÉN, 7, (Madrid, 2007): 17-21.

9 Odón de Buen y del Cos fundó el Instituto Español de Oceanografía en 1914 y desde 1924 presidió la Sección de Oceanografía de la Unión Internacional de Geodesia y Geofísica. Véase; BUEN, 2003.

10 Fue nombrado delegado de España en la Sección de Oceanografía Física de la Unión Internacional de Geodesia y Geofísica y en la Comisión Internacional del Mar Mediterráneo.

11 BOSCH GIRAL, 2010: 187-222. 
de determinadas materias. Cultivo de la ciencia que tuvo muy presente en estos años, en los que no olvidó tanto su procedencia académica como sus firmes deseos de opositar a cátedra en la capital de España. Empeño no exento de dificultades, sobre todo por su militancia política que le hizo estar bajo permanente sospecha, cuando no perseguido y detenido, como tendremos ocasión de exponer más adelante. Con ese fin no dudó en opositar durante el régimen político de Primo de Rivera ${ }^{12}$, según confiesa en el siguiente testimonio:

Con Luis Bermejo, que posteriormente fue Rector de la madrileña Universidad Central en la dictadura de Primo de Rivera, hicimos oposiciones Antonio Medinaveitia y yo a Química Orgánica de Ciencias. Fuimos víctimas los dos de un enorme atropello y le dieron la cátedra a Bermejo. Otras oposiciones hice al Instituto de Farmacobiología y para no darme plaza pusieron unos ejercicios prácticos dificilísimos que resolví pero declararon las plazas desiertas. Dos meses después aprobaban ocuparlas, mediante Real Orden, a dos jueces de esas oposiciones. Era entonces ministro de la Gobernación Martínez Anido que me perseguía mucho. Fue Presidente del Tribunal José Casares Gil, posterior falangista distinguido que a pesar de sus 84 años bulle todavía ${ }^{13}$.

Como puede apreciarse sus condiciones a la hora de enfrentarse a un tribunal eran complicadas, no por falta de preparación, sino por el contexto político escasamente propicio para facilitar sus aspiraciones ${ }^{14}$. Lo mismo podemos decir del citado colega en esos fines Antonio Medinaveitia, otro profesor que al igual que Giral sufría la animadversión del régimen ${ }^{15}$. Éste tuvo en la figura del general Severiano Martínez Anido a un gran valedor de sus esencias. Buen amigo del dictador, destacó en la utilización de métodos represivos para preservar el orden tanto en el ejercicio del cargo de Gobernador Civil de Barcelona de 1920 a 1922, como en calidad de ministro de Gobernación entre 1925 y 1930, que persiguió a opositores como Giral, aunque protegió a valedores como el referido José Casares Gil ${ }^{16}$.

12 TUSEL, 1987.

13 AHN, JG, Legajo n 8

14 GONZÁLEZ CALLEJA y RIBAGORDA ESTEBAN, 2013.

15 Antonio Medinaveitia alcanzó, finalmente, la cátedra de Química Orgánica y fue director del Laboratorio de Química de la madrileña Residencia de Estudiantes, marchando al exilio en México en 1939, país en que fundó el Instituto de Química de la Universidad Nacional Autónoma de México. OTERO CARVAJAL, 2006: 123-124.

16 Nacido en Santiago de Compostela en 1866, farmacéutico y catedrático de Química, José Casares fue miembro durante la dictadura de Primo de Rivera de la Asamblea Nacional Consultiva como representante de Actividades de la Vida Nacional. Cuando Giral escribía este testimonio, década de los cuarenta del pasado siglo, Casares era procurador en las Cortes franquistas. Falleció en 1961. VV. AA. 2005. 
Dificultades para acceder a la cátedra que lejos de disuadir a Giral reforzaron sus deseos de conseguir ese objetivo. Tenacidad que se vio recompensada con su obtención, como pone de manifiesto en el siguiente testimonio:

En julio de 1927 volví a hacer oposiciones a la cátedra de Química Biológica, siendo la octava y última oposición a cátedra que realicé. La había dejado vacante, por jubilación, mi maestro José Rodríguez Carracido. Él mismo presidió el Tribunal. Como la cátedra era del Doctorado de Medicina, Farmacia, Ciencias Químicas y Ciencias Naturales, hubo un Juez de cada Facultad de éstas (respectivamente los señores Juan Negrín, Obdulio Fernández, Bermejo y García Varela). Eliminaron al único contrincante que tenía en el tercer ejercicio, me quedé, por tanto, sólo para continuar pero sabedor de ello Martínez Anido pensó en encarcelarme para impedir que fuese catedrático. Lo supe a tiempo y se lo dije a Obdulio Fernández y éste a Carracido. Hice un fin de semana los últimos ejercicios. El domingo me votaron por unanimidad, a la semana siguiente estaba en la cárcel Modelo pero ya era catedrático de la Universidad de Madrid y le gané la partida al bondadoso Ministro, que se enfadó mucho y se vengó prolongando sin ningún motivo mi detención.

La cátedra, pues, correspondía a su maestro José Rodríguez Carracido (Santiago de Compostela, 1856 - Madrid, 1928), químico y farmacólogo, que no dudó en proteger, como ya lo había hecho en otras ocasiones, a su discípulo Giral ${ }^{17}$. Con ese fin no le importó presidir el tribunal de oposición, acompañándole, entre otros, su también discípulo Obdulio Fernández Rodríguez ${ }^{18}$, Antonio García Varela, Catedrático de Organografía y Fisiología Vegetal de la Facultad de Ciencias de la Universidad Central ${ }^{19}$, y otros que serán posteriormente más conocidos como el catedrático de Fisiología, Juan Negrín Ló$\mathrm{pez}^{20}$. En suma, a punto estuvo de ver truncado su deseo de obtener la cátedra ante la vigilancia a que era sometido desde Gobernación, pero sabedor de que

17 CHAVES PALACIOS, 2012: 195-216.

18 Era natural de la localidad burgalesa de Frías y fue el primer catedrático de la especialidad de Química Orgánica en la Universidad Complutense de Madrid, dedicando gran parte de sus conocimientos, ampliados en Suiza y Alemania, a diversos aspectos de la aplicación de la química al ámbito industrial. Gozó de una vida longeva, falleciendo en 1982 cuando contaba la edad de 98 años. EL PAIS, 1982.

19 Antonio García Varela (1875-1942), de Carballino (Orense), en 1905 obtuvo por oposición la plaza de Auxiliar de Entomología. Ese mismo año viajó a París y Berlín, completando su formación en sus Museos de Ciencias Naturales. Al año siguiente, a su regreso a España, consiguió por oposición la cátedra de Biología y Geología del curso preparatorio de ciencias en la Universidad de Santiago de Compostela, en la que permaneció hasta 1920, año en que se incorporó a la cátedra de Organografía y Fisiología Vegetal de la Facultad de Ciencias de la Universidad Central. GIRAL, 1994; OTERO CARVAJAL, 6, (Madrid, 2001): 149-186.

20 MORADIELLOS, 2006. MIRALLES, 2003. 
iban a por él precipitó los acontecimientos y consiguió su objetivo con la anuencia del tribunal21.

\section{ACTIVIDADES DE LA OPOSICIÓN MONÁRQUICA}

$\mathrm{Y}$ es que independientemente del ejercicio de sus funciones profesionales lo cierto es que Giral, al igual que hiciera en sus años en Salamanca, continuó en Madrid con la práctica clandestina de oposición a la monarquía de Alfonso XIII, como exponemos a continuación:

Desde el advenimiento de la dictadura de Primo de Rivera no cesé en laborar contra ella. Recibía y repartía hojas clandestinas, formaba grupos de Acción Republicana, trataba en unión de otros significados republicanos de unir los partidos y personalidades destacadas del republicanismo para una obra conjunta. Organicé suscripciones pro-presos políticos, hacía frecuentes viajes al extranjero para ponerme en relación con los expatriados... Además en mi laboratorio se celebraban numerosas reuniones ${ }^{22}$.

Nos encontramos, pues, ante una persona que desde su posición contribuyó, con modestia y tesón, al advenimiento de la República. Así, en el Instituto Español de Oceanografía aprovechaba sus viajes al extranjero para entrar en contacto con políticos españoles contrarios a la dictadura de Primo de Rivera como fue, en el caso de Francia, con Carlos Esplá o el conservador José Sánchez Guerra. Además la rebotica de Atocha 35 se convirtió en un lugar de encuentro habitual de los republicanos en Madrid, especialmente tras el golpe militar del Capitán General de Cataluña en septiembre de $1923^{23}$. Sobre esas reuniones en la farmacia señala Giral:

Mis amigos entraban por la farmacia, pasaban a la rebotica, subían al piso y bajaban por la escalera que daba al portal burlando la vigilancia: tenía policías que se estacionaban en la acera de enfrente. Continué conllevando la ciencia y la política

21 En plena Guerra Civil y por disposición aprobada en zona franquista, se le separó de la Universidad (Boletín Oficial del Estado, 20-I-1938). Y un año después, otra Orden ratificaba su separación definitiva de la Universidad (Boletín Oficial del Estado, 17-II-1939). La cátedra de Bioquímica la recuperó en el exilio en México, en el Instituto Politécnico, en donde estuvo ejerciéndola hasta que le designaron Presidente del Gobierno en agosto de 1945. Después de dejar el cargo no pudo recuperarla, permaneciendo a la espera, en febrero de 1948, que le designarán profesor en la Universidad Nacional Autónoma de México, a los 43 años de haber ganado la primera cátedra universitaria en Salamanca. BOSCH GIRAL, 2010: 187-222.

22 AHN, JG, Legajo 8.

23 ÁLVAREZ REY, 2006. 
con la farmacia, con una aclaración: la primera me dio trabajo y fama, la segunda fama y disgustos, la tercera me dio dinero ${ }^{24}$.

Afirmaciones que ponen de manifiesto cómo su establecimiento se convirtió en centro de conspiración en esos años pese a encontrarse bajo constante sospecha policial. Igualmente sus aseveraciones finales muestran la dicotomía de su peripecia vital. Por un lado su actividad profesional, que le reportaba dinero y posición social; por otro su labor política, en la que si bien alcanzó relevantes puestos y llegó a vivirla con esperanza y deseos de transformación, con frecuencia se convirtió en fuente de contrariedades y desvelos tanto para él como para su familia.

Actividad política que fomentó tan pronto se instaló en Madrid en 1920. Para entonces ya se encontraba en esta ciudad su amigo desde la etapa salmantina, Enrique Martí Jara ${ }^{25}$, que había pedido la excedencia en su cátedra de Derecho Político en la Universidad de Sevilla, ciudad a la que se había trasladado desde Salamanca el mismo año en que Giral llegó a Madrid, para trabajar como Vicesecretario del Consejo Superior Bancario. En estos años ambos consolidaron su amistad en compañía de Antonio Marsá Bragado, padre del entonces socialista y no menos revolucionario: Graco Marsá Vancells ${ }^{26}$.

Los tres impulsaron en 1921 Escuela Nueva, una especie de extensión universitaria destinada a los obreros ${ }^{27}$, dirigida por Manuel Núñez de Arenas ${ }^{28}$.

24 AHN, JG, Legajo 8.

25 Enrique Martí fue premio de licenciatura de la Facultad de Derecho de Madrid en 1911. Catedrático de Derecho Administrativo por la Universidad de Santiago de Compostela en 1918 y la de Salamanca en los dos años siguientes, ingresó en 1920 en la Agrupación Socialista de esa localidad. Posteriormente ejerció la cátedra de Derecho Político en la Universidad de Sevilla. Tras el golpe de Primo de Rivera solicitó la excedencia y se trasladó a Madrid. En 1924 sustituyó a Manuel Núñez Arenas como secretario de la Escuela Nueva de Madrid y en 1925, junto a José Giral y Manuel Azaña, participó en la constitución de Acción Política, luego Acción Republicana. Falleció en Madrid en agosto de 1930. www.fpabloiglesias.es/archivo-y-biblioteca/diccionariobiografico/biografias.

26 Antonio Marsá Bragado (1877-1965). Estudió Derecho en Madrid y Barcelona. Inició su actividad política colaborando con Francisco Pi y Margall en el Partido Federal y poco después con Nicolás Salmerón en Unión Republicana. Fue miembro de la Escuela Nueva de Madrid. En 1926 figura como fundador de Alianza Republicana desde las filas del Partido Radical de Alejandro Lerroux. En 1933-1934 ocupó el cargo de Fiscal General de la República y posteriormente miembro del Consejo de Estado. Pasó la guerra civil en Barcelona. Tras su finalización estuvo desterrado en Pamplona tres años regresando a Madrid en 1942 donde vivió, convertido al catolicismo, hasta su fallecimiento el 12 de octubre de 1965. Era el padre de Graco Marsá Vancells, socialista y activo opositor a la dictadura de Primo de Rivera, por lo que fue detenido en varias ocasiones. www.fpabloiglesias.es/archivo-y-biblioteca/diccionariobiografico/biografias.

27 POZO ANDRÉS, 22-23 (Madrid, 2003-2004): 317-346.

28 Manuel Núñez de Arenas (1886-1951), ingresó en la Agrupación Socialista de Madrid 
Escuela Nueva era, en opinión de Giral: «una imitación a las sociedades Fabianas de Inglaterra pero que vivió siempre lánguidamente». La instalaron cerca del local del Ateneo, en el número 11 de la madrileña calle Prado, donde había estado con anterioridad la sede de la revista España. Sobre sus actividades indica Giral:

Entre esos dos centros, la Escuela Nueva y el Ateneo, nos pasábamos la vida, aparte de las ocupaciones profesionales. Los tres organizamos las conmemoraciones de la Primera República el 11 de febrero durante todos los años de la Dictadura. Banquetes en muchos sitios pero principalmente uno, creo que en el año 1925, que se celebró en el mismo local de la Escuela y al que asistieron, entre otros, Lerroux, Marañón, Pérez de Ayala, Azaña y Marcelino Domingo, estando presidido por Álvarez Buylla.

Respecto a su referencia a las conmemoraciones de la Primera República los once de febrero, éstas tuvieron su punto de partida en el permiso concedido con ese fin por el Directorio Civil en 1926, decisión que llevó implícita la reactivación de las asociaciones republicanas. Celebraciones que tuvieron lugar por iniciativa del grupo Escuela Nueva y que culminaron con la fundación de Alianza Republicana, con objeto de coordinar la actividad de todos los grupos afines que conservaron su personalidad independiente.

Pero hasta que eso tuvo lugar cabe señalar que a comienzos de 1924 se celebró una reunión en su farmacia que convocaron los tres coordinadores de Escuela Nueva: Enrique Martí Jara, Antonio Marsá y él con miembros representativos de la oposición monárquica ${ }^{29}$. Sobre el sentido de esta reunión y su proyección posterior afirma:

Pretendíamos unir a todos los republicanos significados y comenzamos por organizar el grupo de Acción Republicana para lo cual recabamos el concurso de Azaña, sacándole de su Ateneo y de sus labores literarias. Primeramente constitui-

en 1911, creando ese mismo año la Escuela Nueva. Fue colaborador asiduo de la revista España, de la que fue redactor-jefe durante algún tiempo. Dirigió la Internacional de Madrid entre 1920-1921. Fue miembro del Comité Central del PCE y candidato por Madrid de este Partido en las elecciones generales de 1923. Perseguido por la dictadura se exilió a Burdeos en 1924, donde fue profesor de su Universidad. Regresó a España al proclamarse la Segunda República siendo catedrático de francés en Alicante y en el Instituto Velázquez de Madrid. Exiliado de nuevo a Francia en 1939, participó activamente en la resistencia al nazismo por lo que estuvo encarcelado entre 1942-1943 en Burdeos y Fresnes. A partir de 1945 volvió a desarrollar actividad científica y académica en la Universidad de Burdeos y desde 1948 dio clases en la Escuela Normal Superior de Saint-Cloud. Falleció en París el 9 de septiembre de 1951. www.fpabloiglesias.es/archivo-y-biblioteca/diccionario-biografico/biografias.

29 Asistieron a esta cita en su farmacia el socialista Julián Besteiro, que sólo fue a este primer encuentro, Manuel Azaña, Marcelino Domingo, Alejandro Lerroux, Roberto Castrovido e Hilario Ayuso. 
mos «Las Novenas». La primera original la formaban el mismo Azaña, que escribió el manifiesto, Araquistain, Jiménez de Asúa, Pérez de Ayala, Teófilo Hernando, Honorato de Castro y nosotros tres (Martí Jara, Marsá y yo). Cada uno de los miembros de esta «novena central» organizaba otra y así sucesivamente. Pasado el verano de 1924 se deshizo esta organización porque se separaron de ella Asúa y Araquistain que se fueron al socialismo, Ayala quedó suelto y luego se agrupó en «Al servicio de la República». Entonces se constituyó el «Grupo de Acción Republicana» con Azaña a la cabeza. Nuevo manifiesto de él y en unión de Lerroux, Domingo, Ayuso y Castrovido se constituyó Alianza Republicana, que funcionó mucho tiempo con esa directiva y nosotros tres como secretarios. Seguimos las reuniones en mi farmacia hasta 1926 que las continuamos todas las semanas en casa de don Alejandro ${ }^{30}$.

Destacamos en el anterior testimonio su referencia a Manuel Azaña. En este sentido cabe señalar que su amistad con él se remonta a su etapa en Salamanca $^{31}$, aunque fue a partir de estas iniciativas políticas durante la dictadura cuando profundizaron en un conocimiento recíproco que les hizo compartir fraternidad, militancia y praxis política ${ }^{32}$. Igualmente resaltar que ambos fueron protagonistas de la fundación de Alianza Republicana a principios de 1926. Firmaron su manifiesto de constitución Manuel Azaña, por Acción Republicana; Hilario Ayuso, por el partido Republicano Federal; Roberto Castrovido, por la prensa republicana; Marcelino Domingo, por el partido Republicano Catalán; Alejandro Lerroux, por el partido Republicano Radical y Giral, Marsá y Martí Jara por la secretaría de la Junta. También se unieron al manifiesto un grupo de intelectuales entre los que se encontraban Miguel de Unamuno, Antonio Machado, Gregorio Marañón, Juan Negrín y Ramón Pérez de Ayala ${ }^{33}$. Al margen quedaron, además de otros colectivos de menor entidad, la mayor parte de los republicanos catalanes que no estaban dispuestos a pactar con Lerroux.

Alianza Republicana amplió pronto sus seguidores, estando en ella representados un nutrido grupo de ateneístas, profesores, escritores, médicos e ingenieros, entre otros colectivos. Igualmente, las tensiones en el seno del republicanismo se tradujeron a veces en desencuentros. Así, en una de sus asambleas clandestinas celebrada en el hotel Calero, situado en el número 2 de la madrileña calle Hortaleza, se gestó una de sus escisiones. Estuvo protagonizada por Marcelino Domingo que se unió a Álvaro de Albornoz y consti-

30 Es preciso aclarar que «Las Novenas» que proliferaron durante aquellos años se denominaban así porque se reunían grupos de sólo nueve individuos con objeto de no incurrir en la figura delictiva de reunión ilegal. JULIÁ, 2008: 235

31 CHAVES PALACIOS, 2012: 195-216.

32 Véase sobre esta relación; JULIÁ, 2008: 235; EGIDO LEÓN, 1998: 155.

33 No estaba en ese grupo José Ortega y Gasset que más tarde fundó la Agrupación al Servicio de la República. DARDÉ MORALES, XVI-2: 130-156. 
tuyeron, en julio de 1929, el partido Radical Socialista. Divisiones y desavenencias que sin embargo no acabaron con Alianza Republicana que siguió vigente y conspirando hasta el advenimiento de la República, como reconoce el mismo Giral:

Unas veces por Alianza, otras particularmente por nosotros, especialmente Martí Jara y yo, intervenimos en muchas conspiraciones y fuimos detenidos varias veces. Las hojas clandestinas de El Murciélago (se tiraba en el Instituto Oceanográfico), Hojas Libres (de Eduardo Ortega y Gasset, desde Hendaya) y otras muchísimas sueltas, se repartían desde el Ateneo y se guardaban principalmente en mi farmacia. Sufrí numerosos registros policíacos en mi establecimiento pero nunca descubrieron nada pues estaban escondidas entre la gran cantidad de específicos y drogas del almacén.

Sobre su referencia a El Murciélago, aclarar que esta publicación ya existía en el siglo XIX. Su contenido entonces ya era crítico con la monarquía, siendo citada, entre otros autores, por Benito Pérez Galdós ${ }^{34}$. En cuanto a Hojas Libres, señalar que su primer número se publicó el uno de abril de 1927 en Francia, siendo director y administrador Eduardo Ortega y Gasset, que contó con la colaboración especial de Miguel de Unamuno ${ }^{35}$, su compañero durante buena parte del exilio francés. Era mensual y salieron a la luz pública un total de 19 números ${ }^{36}$, hasta que las autoridades francesas obligaron a Eduardo Ortega a alejarse de la zona fronteriza. Denunciaba en su contenido los males de España, sus causantes, las malas artes que se practicaban en la política. Se distribuía en la clandestinidad y, pese al riesgo inherente a tenerlas almacenadas, la farmacia de Giral fue uno de los locales madrileños donde se depositaron ejemplares para su distribución.

También cabe ubicar en estos años su ingresó en la masonería. Una decisión, hacerse masón, que le venía de familia pues cuando en plena niñez se trasladó de Cuba a España, la familia que le tuvo acogido, concretamente su tío Aniceto, era masón ${ }^{37}$ y republicano. Éste supo transmitir a su sobrino

34 PÉREZ GALDÓS, 2011: 36.

35 Al parecer con la distribución de Hojas Libres la mujer de Unamuno, Concha Lizárraga, tuvo un percance. Fue a pasar las Navidades de 1927 con su marido en Hendaya (Francia) y al regreso metió varios ejemplares de Hojas Libres entre sus pertenencias. En la frontera registraron su equipaje y los encontraron, siendo detenida y encarcelada, aunque a las pocas horas fue puesta en libertad sin cargos. CASTAÑEDA, 2008: 191.

36 El alcalde y diputado por Bayona, Garat, hizo las labores de gerente del semanario que se editaba de la imprenta Rénovatrice. Cada número, con formato de bolsillo, constaba de 96 páginas y al precio por unidad de 1,50 pesetas, siendo la primera tirada de cinco mil ejemplares. RABATÉ, 2009.

37 Su tío era alto cargo en la masonería: Grado 33. 
principios tan necesarios para desenvolverse en la vida como los de austeridad y prudencia, así como el sentimiento laico que le caracterizó a lo largo de su existencia ${ }^{38}$. Fue en 1926 cuando dio ese paso, concretamente ingresó en la Logia Dantón, en la capital de España, en la que se agruparon para conspirar contra la monarquía personajes tan conocidos como Marcelino Domingo, Albornoz, Casares, José Salmerón, Martí Jara, Marsá, Sarabia, Lezama y Escudero, entre otros.

Sin embargo, en cuanto al desarrollo de actividades en la «Orden», no tiene empacho en reconocer «que había actuado muy poco, no siendo su dedicación activa ni constante». Igualmente reconoce que él fue la persona que condujo a Manuel Azaña a la masonería, en la que ingresó en el año $1931^{39}$. Ejercicio como masón que Giral mantuvo en su exilio en tierras mexicanas, aunque en la misma tónica anterior: «apenas asistí a reuniones y tenidas». Excepción aparte en sus viajes por países latinoamericanos, en que tuvo que asistir a diversos encuentros organizados por compañeros de hermandad.

Por tanto el ingreso en la masonería fomentó su oposición al régimen de Primo de Rivera, como lo pone de manifiesto su participación en dos de los conflictos a los que tuvo que hacer frente el dictador en 1926: la «Sanjuanada» y la cuestión artillera. Esta última dio lugar a un desencuentro entre artilleros que si bien pudo ser resuelto, deterioró la imagen del monarca en ese cuerpo de ejército al no apoyarle en sus demandas ${ }^{40}$. Y en cuanto a la «Sanjuanada», conocida con esa denominación por haber tenido lugar la noche del 24 de junio de referido año, fue una conspiración política y militar para restablecer el orden constitucional que según José Giral fue organizada, entre otros, por el capitán Juan Perea Capulino ${ }^{41}$ (muy amigo de Marcelino Domingo), el general Francisco Aguilera ${ }^{42}$ y miembros de Alianza Republicana.

La consecuencia de esta conspiración, rápidamente liquidada, se advierte en el nuevo talante de Primo de Rivera, que hablará, por primera vez, de una posible reforma constitucional, así como de convocar una «Asamblea deliberante de Cortes», cuyas atribuciones, sin embargo, no se especificaban ${ }^{43}$. Con

38 CHAVES PALACIOS, 32 (Valladolid 2012): 195-216.

39 Otros autores señalan que su ingreso en la masonería fue en 1932 con el grado de aprendiz. EGIDO LEÓN, 2006: 156.

40 GÓMEZ NAVARRO, 1995: 381.

41 Fracasada la intentona, Perea Capulino fue juzgado y condenado a seis años de prisión, siendo internado en el Castillo de Montjuich en Barcelona. PEREA CAPULINO, 2007.

42 Este general se convirtió en serio opositor de Primo de Rivera, estando presente en las conspiraciones y movimientos opositores contra la dictadura de 1926 y 1929. En mayo de 1931, pocos días antes de su muerte, el presidente del Gobierno Provisional de la República le ascendió a capitán general por los eminentes servicios que había prestado a la causa de la libertad. ALÍA MIRANDA, 2006.

43 JOVER y GÓMEZ-FERRER, 2001: 507-574. 
todo, estos movimientos contribuyeron a que el dictador se planteara la posibilidad de una institucionalización estabilizadora de su régimen en los meses inmediatamente siguientes ${ }^{44}$. No obstante, la realidad fue que a la creciente movilización obrera, estudiantil y política contra el régimen, éste respondía con más medidas represivas.

\section{IMPLACABLE PERSECUCIÓN CONTRA LOS DISIDENTES}

La persecución de los principales cabecillas de la oposición republicana constituyó una constante, siendo un claro ejemplo lo sucedido a José Giral. Éste ya sabía lo que era estar en la cárcel, pues había estado recluido en el centro penitenciario de Salamanca dos meses a consecuencia de la huelga revolucionaria de 1917. Y en tiempos de Primo de Rivera volvió a pasar por esa experiencia en varias ocasiones, en este caso en la madrileña cárcel Modelo («hotel de la Moncloa» la denomina Giral) ${ }^{45}$. En concreto, su primera detención en la capital de España se produjo en noviembre de 1926, siendo este su testimonio:

Nos detuvieron a Martí Jara, Graco Marsá (por su padre Antonio) y a mí. Todos directivos de Escuela Nueva. Nos instalaron en la célebre Quinta Galería de la cárcel Modelo que es la destinada para los delincuentes de delitos de sangre y para las celdas de castigo. Estuvimos rigurosamente incomunicados. Mi celda apenas tenía 3 metros de largo por 2 de ancho. Un orificio en un rincón que servía de retrete maloliente (ciertamente no inodoro), un petate lleno de piojos que se doblaba sobre una de las paredes (jergón de paja, una sola sábana bien sucia, una manta y una almohada sin funda, una mesa de madera empotrada en la pared, una palangana y ... nada más). No salíamos de paseo ni tomábamos el aire, sin poder leer, no nos permitían tener lápiz, ni pluma, ni papel, ni tijeras, ni vaso de vidrio ni más cubiertos que una cuchara de peltre de mando muy corto (parecía un calzador); ni libros ni periódicos ni máquina de afeitar ni nada. El agua nos la servían por el rastrillo de la puerta: se colocaba la palangana por el lado de dentro y por el de fuera el repartidor del agua sacaba ésta con un bote de conservas vacío (de un cubo infecto) y la vertía en la palangana. Uno bebía luego a bruces o con la cuchara disminuida. No se podía retener agua por no haber vasija para guardarla ya que la jofaina había de utilizarse para lavarse. Yo entretenía los 10 días que así estuve en

44 GONZÁLEZ CALLEJA, 2005.

45 Este centro penitenciario fue proyectado por los arquitectos Tomás Aranguren y Eduardo Adaro. Comenzó su construcción en el año 1877 y no se inauguró hasta siete años después, siendo el penal de mayor tamaño de Madrid. Estuvo en funcionamiento hasta el año 1939 en que ante el deterioro sufrido a causa de los bombardeos y el funesto recuerdo del recinto, los vencedores de la Guerra Civil decidieron su demolición y la edificación de un nuevo penal en Carabanchel. 
hacer gimnasia. Una vez se me ocurrió cantar y el oficial de prisiones indignado me lo prohibió. Me servían el rancho de la cárcel pues no dejaban traer viandas de casa. Durante la comida se abría la celda y el oficial vigilaba. Esos días fueron terribles: ratas, chinches y piojos me hacían una desagradable compañía. Fue la detención más penosa que yo he pasado. Cuando nos levantaron la incomunicación supe que en las celdas contiguas a la mía estaban mis dos amigos antes citados. Parece que sospecharon que estábamos en relación con Maciá que había protagonizado aquella ridícula asonada militar en Prat de Molló. El frío en aquella época y en aquella celda era una cosa atroz. Tras levantarnos la incomunicación nos prolongaron la detención por dos meses más. No nos procesaron.

Respecto a las razones que originaron esta detención, guarda relación con los actos protagonizados por Francés Maciá 46 avanzado el otoño de 1926, y su intento de invadir Cataluña desde Francia con una columna de voluntarios. La expedición no llegó a tierras españolas al ser detenido por la policía francesa tanto referido líder ${ }^{47}$ como parte de sus seguidores ${ }^{48}$. «Ridícula asonada», la califica Giral, que sin embargo originó una vuelta de tuerca del régimen en materia represiva, con estas detenciones y la de otros opositores políticos.

Igualmente es necesario destacar la precisa y detallada descripción que realiza de la celda en la quinta galería en que estuvo encerrado e incomunicado, poniendo de manifiesto el pavoroso estado en que se encontraba este centro penitenciario y, sobre todo, el trato vejatorio que recibían los reclusos ${ }^{49}$. Una experiencia, como bien indica, inolvidable, que sin embargo no consiguió los efectos de resignación y escarmiento del recluso, que continuó, una vez en libertad, sus labores de oposición a la monarquía.

Actividades que nuevamente originarían su visita a esta prisión. Así, en el año siguiente, como ya hemos hecho referencia con anterioridad, tras obtener la cátedra en Madrid volvió a ser detenido y encarcelado. Dejó constancia de esta nueva experiencia en los siguientes términos:

Estuve en celda de políticos bastante bien: cama regular, comunicación con los visitantes desde la misma celda, comidas seleccionadas que recibía de casa, horas de paseo y recreo, comunicación en la galería con los otros detenidos, libertad de conversación, lecturas abundantes, etc. Estaba entonces detenido Lerroux a quien tuvieron que sacar pronto porque tenía un ántrax en el cuello que resultó maligno.

46 Véase sobre este controvertido personaje; ROIG ROSICH, 2006.

47 Le condenaron a dos meses de cárcel, siendo después deportado a Bélgica. Tras permanecer en ese país y en otros no regresó a España hasta febrero de 1931. Véase; UCELAY DA CAL, 1984.

48 SUEIRO SEOANE, 5, (Madrid, 1992): 385-396.

49 La Segunda República trató de mejorar la situación de los presos y las cárceles en relación a etapas pretéritas. GARGALLO VAAMONDE, 2011: 41. 
Mi mujer ya se iba acostumbrando a estas detenciones y la pobre se esmeraba en prepararme comida y en ir a verme todos los días.

Como puede apreciarse esta estancia en la cárcel fue más soportable al permanecer en unas dependencias diferentes a la anterior, que le permitían relacionarse con otros presos, entre ellos el líder de la formación Republicana Radical: Alejandro Lerroux. También podía comer la manutención que a diario le llevaba su abnegada mujer, María Luisa. En suma, esta segunda estancia en el «hotel de la Moncloa», pese a las incomodidades inherentes a estar preso y tener que ceñirse a la disciplina carcelaria, fue más llevadera y eso se aprecia en su testimonio.

Pero las acciones de la oposición a la dictadura lejos de cesar continuaron si cabe con mayor intensidad a medida que se acercaba el final de la década. Así el socialismo que se había mantenido hasta 1929 al margen de estos movimientos, a partir de ese año PSOE y UGT rompieron esa neutralidad y se inclinaron a favor de la república y democracia ${ }^{50}$. Por su parte las anarquistas CNT y FAI intensificaron su proceso de aproximación, mientras que la detención de comunistas, tras participar activamente en procesos huelguísticos en el norte de España, se convirtió en objetivo prioritario del régimen.

Asimismo la Universidad, que había crecido significativamente en número de alumnos desde inicios del decenio, se torna cada vez con mayor rotundidad como una de las instituciones más críticas contra el régimen. Se funda la FUE (Federación Universitaria Española) y los estudiantes se movilizan, destacando la huelga del 9 de marzo de 192951. Esas alteraciones originaron el cierre de la Universidad Central en Madrid, con profesores que abandonaron sus cátedras como protesta y se unieron a la $\mathrm{FUE}^{52}$. Alteraciones académicas que se vieron acompañadas, desde inicios de ese año, por otras que pretendieron derrocar al dictador.

$\mathrm{Y}$ es que con la ya referida «Sanjuanada» no concluyeron los pronunciamientos contra el régimen. El siguiente capítulo en este sentido lo encabezó quien había sido jefe del Gobierno en 1922: José Sánchez Guerra, que se exilió en París tras el golpe de estado de Primo de Rivera y con quien, como ya hemos señalado, Giral mantuvo encuentros en sus viajes a Francia. Fue a finales de enero de 1929 cuando decidió regresar a España para encabezar un levantamiento en Valencia que fracasó y acabó con la detención de los promotores ${ }^{53}$. Este levantamiento, además de la complicidad de otros mandos

50 ANDRÉS GALLEGO, 1977.

51 BEN AMÍ, 1984: 229.

52 Entre esos profesores destacaron Ortega y Gasset, Jiménez de Asúa, Sánchez Román y Fernando de los Ríos. JOVER y GÓMEZ FERRER, 2001: 567.

53 MARTORELL LINARES, 2011: 403. 
militares, contó con apoyo civil, entre ellos de José Giral, que narra de esta forma esos contactos:

En enero de 1929 fue lo del desembarco de Sánchez Guerra en Valencia. En ello intervenimos muy directamente Martí Jara y yo. En el despacho de mi farmacia organizamos, con el hoy general Juan Hernández Sarabia, todo el movimiento artillero (con don Pancho Aguilera que se sublevó en Ciudad Real) y con emisarios que despachamos a todas las guarniciones. Lerroux estaba entonces aplicándose glándulas por el tratamiento de Voronoff, Azaña estaba de Juez de Notaria en Valladolid. Por eso lo hicimos sólamente Jara, Pepe Salmerón, Sarabia y yo.

Por tanto participó en las actividades de una operación en que se confiaba que hubiera veintiún regimientos de Artillería implicados, junto a algunos más de Infantería, Caballería y Aviación. Todo debía iniciarse en la madrugada del 28 al 29 de enero, pero la realidad es que sólo se sublevó el primer Regimiento de Artillería Ligera de Ciudad Real ${ }^{54}$. En cuanto a las personas con las que mantuvo contactos, destacar que el oficial Hernández Sarabia fue durante la Segunda República ayudante militar de Azaña ${ }^{55}$; el general Francisco Aguilera Egea, que era de Ciudad Real, participó en la «Sanjuanada» y en esta insurrección como caracterizado opositor al dictador ${ }^{56}$; y José Salmerón sería en 1929, tras su ruptura con el partido Radical de Alejandro Lerroux, uno de los fundadores del partido Radical Socialista dirigido por Marcelino Domingo ${ }^{57}$.

También destacó en este fracasado levantamiento, de acuerdo con el siguiente testimonio de Giral, otro conspicuo general llamado a tener un especial protagonismo años después:

En este desembarco de Sánchez Guerra en Valencia, Gonzalo Queipo de Llano tomó parte muy activa. Días antes de estallar se fue con Martí Jara a una finca de éste en Alpera (Albacete) en donde recibió su uniforme de general y desde allí partió para Murcia con el propósito de sublevar aquella guarnición. Pero fracasado el movimiento no hizo nada. Tan significado republicano era que tuvo que emigrar y pasar una temporada en París en unión de Hidalgo de Cisneros y otros militares. Como es sabido Niceto Alcalá Zamora le nombró jefe del Cuarto Militar del Presidente de la República.

Presencia, pues, de Queipo de Llano, un general que inicialmente aceptó la dictadura pero que a medida que fueron transcurriendo los años fue mostrando su animadversión al régimen, hasta el punto de participar en las conspira-

54 MARTORELL LINARES, 2011: 406.

55 AROCA MOHEDANO, 2006.

56 ALÍA MIRANDA, 2006: 209.

57 RUIZ MANJÓN, 1976: 145. 
ciones contra Primo de Rivera. En este caso, efectivamente, su función era llevar la insurrección hasta tierras murcianas, misión en la que, en línea con lo sucedido a este levantamiento, fracasó. Consiguió huir hasta que, finalmente, fue detenido ${ }^{58}$, teniendo que marchar al exilio a Francia, país en que continuó sus labores de oposición al régimen.

Pero protagonistas aparte, lo cierto es que esta insurrección tuvo consecuencias para Giral que volvería a ser detenido, permaneciendo en prisión desde febrero a mayo de 1929. Encarcelamiento que vino precedido de una contingencia sanitaria verdaderamente inusual, según exponemos a continuación:

Dispuesto el levantamiento, ante el temor a ser detenido me recluí en el sanatorio del Pilar (Paseo de la Ronda, junto a la Guindalera), dirigido por el doctor Tomás Rodríguez Mata (hijo mayor de Hipólito Rodríguez Pinilla). Este último me sirvió de enlace. Mi familia no sabía de esta reclusión y como estaba alarmada hubo de hacerse conocer el sitio donde estaba y allí fue la Guardia Civil a detenerme. Fue necesario simular una operación de apendicitis para evitar ser detenido y enviado a prisión. Tengo siete puntos de sutura en el bajo vientre. La simulación de la operación no la conocían más que el médico y una enfermera de toda confianza. Me preparó este amigo cirujano rasurando y esterilizando la parte que iba a operarse, me anestesiaron con éter y me hicieron una profunda incisión de unos 20 centímetros de longitud, simulando la habitual en la operación de apéndice. Me dieron siete puntos de sutura y conservo la cicatriz de esta auténtica chiquillada que hice a mis 50 años. Las sospechas de la policía tenían fundamento, pues no tardó en presentarse en mi busca, horas después, y me establecieron dos guardias civiles de uniforme y chafarote a la cabecera de la cama que alarmó al personal del Sanatorio que creyó era un peligrosísimo criminal. Pronto los sustituyeron por agentes de la secreta a quienes se les habilitó una habitación contigua para que reposasen cuando no estuvieran de turno de vigilancia. Por cierto que uno de los policías, sorprendido ante las precauciones tan desusadas contra mi persona, me preguntó si yo era coronel, pues no podía suponer categoría inferior para tanto aparato. Al contestarle que era catedrático, dijo sencillamente:

- ¡Lo que habrá tenido que estudiar para eso!

Me hice muy amigo de todos ellos y a algunos los conquisté para «Acción Republicana». La complicidad llegó a un punto que hasta les daba yo permiso para que salieran a dar un paseo.

Los dos meses que permanecí en el sanatorio fue con vigilancia permanente en mi alcoba. El médico militar que me visitaba se dio enseguida cuenta de la simulación y toleró que siguiese ingresado hasta que me dio el alta y pasé a mi domicilio, donde tan sólo estuve dos días pues el tercero me detuvieron y fui a la cárcel. Allí estaban detenidos otros compañeros. El juez militar, comandante Arribas, me tomó declaración y no me preguntó más que cuestiones relacionadas con Miguel de

$58 \mathrm{Al}$ parecer se escondió en un castillo propiedad del médico republicano y masón Mario Spreáfico y, posteriormente, fue detenido y encarcelado en una prisión militar. SALAS, 2012. 
Unamuno: si organicé la suscripción para cubrir los haberes de su cátedra, si había organizado también una protesta por su destitución, si me escribía con él, etc. Todo cierto, no dudando en dar mi conformidad a esas preguntas. Al terminar le dije irónicamente si no creía que iba a hacer el ridículo consignando tal declaración en la que no se veía nada punible. Lo reconoció e hizo que el escribiente rompiese todo lo escrito. Pronto llegó mi sobreseimiento y puesta en libertad.

Sospechaba, ante el fracaso de la insurrección, que su detención no se haría esperar y no le importó tratar de evitarla con el ingreso en un centro hospitalario y la simulación de una operación que le dejó como muestra una cicatriz. Ello le haría recordar este suceso durante toda su vida. Su misma mujer así lo reconocía cuando a propósito de las revisiones médicas a que era sometido Giral en el exilio mexicano, éste manifestaba al facultativo que estaba operado de apendicitis. A lo que María Luisa añadía: «el apéndice lo tiene, fue la maldita política, doctor. ¡maldita política!». Con esas expresiones tan contundentes, su esposa manifestaba con amargura la dura experiencia que había supuesto el paso por la política de su marido. Eran palabras que le salían de lo más profundo de su ser y que exponían sin ambages sus impresiones sobre las consecuencias que la proyección pública de Giral había tenido para su entorno familiar.

También cabe destacar la férrea vigilancia a que fue sometido en un centro hospitalario donde debían acompañarle enfermos reales, no imaginarios como era su caso. Creemos que reacciones de este tipo daban buena cuenta de la persecución a que era sometido por parte del régimen y el firme deseo de éste de mostrar una posición de fuerza frente a los devaneos republicanos y sus protagonistas. Igualmente sorprendente resulta que en el procedimiento militar que le abrieron para ser juzgado por estos acontecimientos, lejos de indagar en su relación con estos hechos el interrogatorio se basara en su conocida relación de amistad, desde su paso por Salamanca, con Miguel de Unamuno.

Y si bien sus declaraciones, de acuerdo con ese testimonio, no se tuvieron en cuenta, este hecho pone de manifiesto que el levantamiento que originó su detención había pasado a un segundo plano y en la agenda del Gobierno se imponían otras consideraciones, como era el acoso a figuras tan señeras de la intelectualidad española de entonces como el ex Rector de la Universidad de Salamanca. No dudó Giral en contestar afirmativamente a las cuestiones que le relacionaban con él y, sin embargo, lejos de resultar punibles esas aseveraciones fue liberado poco después. Consideramos que la situación de debilidad del régimen a medida que se acercaba el final de la década, sus contradicciones y la pérdida de liderazgo del dictador tuvieron mucho que ver en ese tipo de decisiones.

Nunca ocultó Giral su amistad con Miguel de Unamuno. Todo lo contrario. En horas de dificultad para éste, como fueron los años de la dictadura de Primo 
de Rivera, supo estar a su lado e hizo todo lo que estuvo a su alcance para defenderle. Su testimonio siguiente es suficientemente aclaratorio al respecto:

Antes de su confinamiento siempre le veíamos cuando pasaba por Madrid y alguna vez le llevamos a la casa misma de Lerroux, a quien no podía ver ni en pintura. Desde que fue destituido de su cátedra y confinado en Fuerteventura, hice grandes gestiones de protesta. Destaco el Manifiesto que firmaron más de 500 personas (catedráticos, escritores, médicos, políticos, etc.), todas muy conocidas, que Martí Jara y yo llevamos personalmente a Primo de Rivera. Nos recibió bastante afectuosamente pero no nos detuvieron por eso, ni el dictador se hizo jamás eco de tal Manifiesto a pesar de lo dado que era a la publicación de sus célebres y abundantes «Notas». Después organizamos una suscripción entre profesores para los haberes de su cátedra y socorrer a su familia. Esto fue lo que principalmente me preguntó el juez comandante Arribas cuando me encarcelaron en 1929.

Desde Fuerteventura primero y luego desde Hendaya y París tuve correspondencia abundante con don Miguel. Sus cartas me llegaban siempre abiertas e invariablemente comenzaban de este modo: «Como sé que esta carta ha de conocerla ese cerdo epiléptico que se llama Martínez Anido, le escribo para usted y para él». Y efectivamente así era. La manifestación enorme y tumultuosa que se hizo en la estación del Norte en Madrid cuando pasó de Salamanca a Cádiz y luego a Canarias, se disolvió a sablazos y resultamos levemente heridos Unamuno (que iba de mi brazo), Martí Jara y yo. La enemistad que personalmente me tenía Martínez Anido se explica por lo que relato; y bien se manifestó entorpeciendo mi labor profesional y científica.

Cuando la dictadura de Berenguer, Martí Jara y yo le organizamos en Madrid un gran recibimiento al retorno de su destierro, después también hicimos el acto del Cinema Europa en el madrileño barrio de Cuatro Caminos, en el que habló solamente don Miguel. Tras finalizar el acto se produjo una manifestación que fue disuelta por la Guardia Civil a caballo.

Estaba, pues, comprometido en la defensa y ayuda de su compañero en las tareas universitarias y amigo, pese a que ello le originó algún que otro disgusto. El ministro de Gobernación, referido general Severiano Martínez Anido, conocía esa relación y como bien señala Giral ese constituyó uno de los principales argumentos esgrimidos por las fuerzas del orden para que fuera perseguido cuando no detenido. Pese a esos inconvenientes su amistad con Unamuno continuó inquebrantable en este período.

En otro orden indicar sobre esta detención, que Giral tuvo como ingrediente especial la compañía de su hijo mayor, Francisco. Éste había finalizado sus estudios de Bachillerato en 1927 y se encontraba cursando la licenciatura en Ciencias Químicas en la Universidad Central de Madrid ${ }^{59}$, habiendo sido detenido por su participación en huelgas de estudiantes universitarios. También

59 AHN, Universidad Central, Sección Ciencias, legajo 5.642, carpeta 15. 
fue recluido en la cárcel Modelo y allí compartió compañía con su padre, como exponemos a continuación:

Me parece que fue esta vez cuando detuvieron e incomunicaron en celda de «pago» (primera galería) a la directiva de la FUE. Entre los ellos se encontraban Sbert y mi hijo Paco. Yo le observaba al pasar, por la mirilla de la celda. Estaba tranquilo y aburrido. Después le levantaron la incomunicación y jugábamos juntos a la pelota en uno de los patios de aquel «Hotel».

Dos miembros de la familia, por tanto, compartiendo destino carcelario por motivos distintos aunque con el mismo origen: su oposición a la dictadura. Y es que su hijo mayor, Francisco, que siguió los derroteros docentes y postulados políticos republicanos de su padre, era miembro de la junta directiva de la Federación Universitaria Española (FUE), en la que destacaba junto a citado Antoni M. Sbert, líder estudiantil que a partir de la Segunda República desempeñó una ingente actividad política ${ }^{60}$.

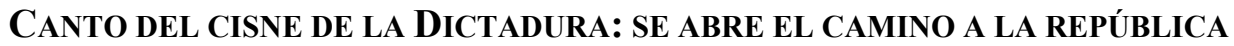

Y el último encarcelamiento de Giral en esta etapa se produjo a finales de 1930, cuando ya el dictador había dejado el poder casi hacía un año y todo apuntaba a que el país se acercaba a un cambio de rumbo político ${ }^{61}$. En esa dirección apuntaba el acuerdo conseguido en agosto de ese año entre los grupos políticos republicanos, socialistas y catalanistas de izquierdas con vistas a una acción común, que se tradujo en el conocido como pacto de San Sebastián ${ }^{62}$. Hecho que Giral vivió en primera persona tanto en sus antecedentes, como en la formación del Comité Revolucionario y su desenlace, según se recoge en el siguiente testimonio:

A mediados de julio de 1930 y estando reunida la directiva de «Alianza Republicana» en casa de Alejandro Lerroux, llamó por teléfono Niceto Alcalá Zamora rogándonos fuésemos algunos de los miembros a su casa con objeto de designar un Comité Revolucionario formado por republicanos y socialistas. Fuimos inmediatamente a verle Manuel Azaña y yo. Propuso la formación de ese Comité con dos representantes por cada partido o agrupación. Por el Conservador Republicano, él y Miguel Maura; por Acción Republicana, Azaña y yo; por el Radical Socialista, Albornoz y Marcelino Domingo; por los socialistas, Largo Caballero y Prieto; por los

60 MASSOT I MUNTANER, 2000: 23.

61 BEN AMÍ, 1990.

62 Uno de sus promotores fue el último alcalde republicano de San Sebastián: Fernando Sasiain Braun. URMENETA y MARKEZ, 2013. 
radicales, Alejandro Lerroux y Diego Martínez Barrio; por la ORGA, Santiago Casares, y por los partidos catalanes los que ellos designaran.

Yo rehusé pues me iba días después a Estocolmo a un Congreso Internacional, como así fue. Además, con Azaña era suficiente representación. El pobre Martí Jara, que estaba ausente de Madrid y ya enfermo, volvió pocos días después y falleció a fines de julio (yo supe la noticia ya en Estocolmo). Le comuniqué a Lerroux el acuerdo alcanzado con Alcalá Zamora en la localidad de San Rafael, en donde veraneaba.

El resto de cuestiones sobre el Pacto y reunión en San Sebastián es bien conocido. Se formó dicho Comité y al finalizar del verano comenzaron a actuar reuniéndose en una habitación retirada del Ateneo que tenía dos puertas (calle del Prado y calle de Santa Catalina). Allí prestábamos vigilancia varios amigos y nunca los perturbó la policía hasta que detuvieron a parte del grupo a mediados de diciembre de ese año. En una de aquellas reuniones decidieron nombrarme (cuando triunfase la República) Gobernador General de Cataluña, decisión que me comunicó Azaña y que rechacé al considerar que no reunía condiciones para ese puesto y estimar que debía desempeñarlo un catalán.

De acuerdo con esa hoja de ruta cabe señalar que fue en el verano de 1930 cuando se aceleraron las labores de oposición, con la formación del referido Comité. Éste hizo público un Manifiesto con sus objetivos, que firmaron todos los miembros y también otros opositores afines como el mismo Giral. Adhesión que fue uno de los argumentos utilizados por las fuerzas del orden en su detención a finales de ese mismo año. Igualmente es preciso destacar, dentro de las actividades del referido Comité, el mitin republicano celebrado el domingo 28 de septiembre de 1930 en la plaza de toros antigua de Madrid, ubicada frente al Parque del Retiro y cerca de la Puerta de Alcalá. En el acto participaron líderes representativos de la oposición monárquica y rebasó toda previsión de asistencia, al contar con la presencia de miles de personas a las que cabe añadir la multitud que permaneció en sus inmediaciones.

No se conocía hasta entonces una convocatoria masiva de tal alcance, poniendo de manifiesto que la monarquía se desmoronaba y que la «marea republicana» se abría paso con firmeza en la política española. Asimismo las medidas de seguridad en torno al coso taurino fueron significativas, con la presencia de destacamentos de la guardia civil, guardia urbana e incluso el ejército. Pese a ello, lo cierto es que tras finalizar el acto apenas se registraron incidentes. Giral asistió y dejó la siguiente semblanza:

El mitin del 28 de septiembre fue impulsado por el Comité Revolucionario y tuve una participación activa en su organización en compañía de otros correligionarios. Fue el primer gran mitin de masas celebrado en España. Asistió gente de toda España. En la plaza de toros vieja destacaban las numerosísimas banderas de centros y agrupaciones políticas republicanas, los servicios del orden controlados por las juventudes, los micrófonos, altavoces... Los asistentes sumaban más de 
20.000 personas y todo el ruedo estaba lleno de sillas con público. A la salida había fuertes retenes de policía y guardia civil con ametralladoras. No hubo incidentes sangrientos. Hablaron Alcalá Zamora, Azaña...

Las repercusiones públicas de este evento fueron notables y supuso un importante impulso para unos miembros del Comité Revolucionario que comprobaban cómo eran perseguidos, hasta el punto de que al finalizar el año estaba prácticamente desarticulado y buena parte de sus integrantes en la cárcel. Y es que en diciembre hubo un intento de huelga general y, sobre todo, tuvo lugar la sublevación de la guarnición de Jaca al mando del capitán Fermín Galán, con la intención de alzar al ejército español y proclamar la República. La asonada fracasó y sus principales cabecillas: citado capitán y el teniente Ángel García Hernández fueron pasados por las armas el domingo 14 de diciembre de $1930^{63}$.

Horas después de esas ejecuciones era detenido en Madrid, junto a otros compañeros de oposición a la monarquía, José Giral, que señala lo siguiente sobre los instantes previos a su encarcelamiento:

La noche del 14 de diciembre de 1930 estaba yo en el Ateneo cuando se supo lo ocurrido en Jaca. Pensamos que nos detendrían enseguida y alguien me ofreció sitio para ocultarme (Manuel Hilario Ayuso que tenía un «nido» para sus citas amorosas); no lo acepté porque aún creía que podría dormir aquella noche en mi cama. No fue así porque a eso de las 2 de la madrugada vinieron a detenerme. Como ya vivía en la calle Blasco Ibáñez $\mathrm{n}^{\circ}$ 4, el camino a la cárcel Modelo era muy corto lo cual comenté con los policías. Llegue al primero de todos los detenidos y pude elegir libremente habitación en aquel hotel que me era ya tan conocido. Me instalé en la mejor celda de políticos, la señalada con la letra $\mathrm{H}$.

Es llamativo comprobar que era consciente, junto con el resto de compañeros republicanos, que cualquier asonada podía afectarles pues estaban bajo permanente sospecha policial. Las noticias de lo sucedido en Jaca, pese a no tener implicación en esos hechos, es un claro ejemplo. Las primeras informaciones sobre lo sucedido les pusieron en alerta y cada cual trató de buscar refugio donde mejor pudo. Giral optó por volver a su domicilio y allí mismo sería detenido. Decisión que no debió sorprender a su entorno familiar, tan habituado a estos contratiempos en los últimos años. Y también dentro de esa experiencia carcelaria cabe encuadrar la de elegir, si se brindaba la ocasión, la mejor celda en el «hotel de la Moncloa». Recinto penitenciario que pronto se pobló de nuevos presos políticos, como él mismo señala:

63 Véase los testimonios de personas que vivieron estos hechos en RIVAS y ANTORANZ, 2011. 
Horas después fueron llegando José Escudero (a quien siempre detenían); el secretario de Lerroux, Sánchez Fuster; los dueños del hotel Florida... Y ya por la mañana ingresaron Largo Caballero, Fernando de los Ríos, Miguel Maura, Alcalá Zamora, Maura, etc. Al día siguiente Albornoz y Galarza que los detuvieron en Alicante y llegaron más tarde. También a Casares Quiroga, Graco Marsá, Carlos Castillo, Lezama y otros que no recuerdo. Se llenaron enseguida las celdas de políticos, que no eran más que unas seis o siete, y se habilitaron las de pago. A una de éstas fue don Niceto. Se habían ocultado para evitar ser detenidos Manuel Azaña, Marcelino Domingo y Alejandro Lerroux. Yo serví de enlace entre ellos y los de la cárcel pues conocía los escondites... En la «Modelo» permanecí hasta finales de febrero de 1931.

Como puede apreciarse, unos fueron encarcelados y otros eludieron a las fuerzas del orden y se escondieron. Suerte dispar, por tanto, para estos significados republicanos que eran conscientes de vivir bajo sospecha y estar bajo el punto de mira de las fuerzas de seguridad del Estado. En los dos meses que estuvo entre rejas convivió con políticos de la oposición a la monarquía que con el advenimiento de la Segunda República acapararán un importante protagonismo. Con la mayoría de ellos acrecentó su amistad en estas semanas de encierro, en una convivencia que como se puede apreciar en el testimonio de Giral que exponemos a continuación, pese a las tensiones originadas por encontrarse en prisión no faltaron ratos lúdicos y de buen entendimiento.

Como entre nuestras celdas nos podíamos comunicar, venían a la mía a hacerlo varios de los mencionados y especialmente don Niceto. Por eso circuló mucho una de las fotos que hizo uno de nuestros vigilantes y en la cual figuramos los dos a través de la reja. Todos nos reuníamos en nuestra galería (que era acristalada, con mucha luz y buena temperatura) a cenar, comer y charlar. Las horas de paseo las pasábamos jugando a la pelota en el patio, especialmente Galarza, Maura, Graco Marsá y yo. La convivencia con tantos ilustres personajes daba lugar a mucho entretenimiento y varios disgustillos. Sánchez Fuster nos tomaba los cigarros puros que en cantidad considerable de caja recibíamos de los visitantes; también lo hacía con las botellas. Se constituyó un almacén de todo ello (caja de habanos, botellas de champagne, jerez, coñac, etc.; fiambres y cajas de dulces, mazapanes, etc.) en mi celda, siendo yo el administrador de todo ese fondo común de «delicatesen». Los visitantes eran en tal número que todos los días pasaban de varios millares haciéndose colas enormes por la calle de Blasco Ibáñez. Y como casi todos nos aportaban alguna cosa, puede imaginarse lo que yo almacené. Algunos regalos fueron espléndidos. A don Fernando de los Ríos le trajeron de Granada un verdadero monumento hecho de mazapán y otros dulces. Creo representaba una estatua de la Libertad. Nos la comimos entre todos (la figura porque la libertad ya nos la habían comido antes).

El bueno de don Fernando era bastante glotón y a la vista de un seductor manjar exclamaba siempre: «esto es una admirable síntesis de la naturaleza». A esta exclamación seguía el engullimiento a dosis masiva de la citada «síntesis». También don Niceto era punto fuerte en lo de comer y los demás hacíamos lo que podía- 
mos, modesta pero insistentemente. De beber vinos generosos don Fernando nos daba lecciones más teóricas que prácticas pues era gran conocedor de bouquet, aromas, etc. Si este vino esta nublado, si tal otro está tierno, si el de allá aún está verde o el otro era sentado, etc. Algunas noches acompañaba sus amenas charlas con el cante de algún fandanguillo o algunas bulerías del más puro estilo. Algunas veces había discusiones más o menos profundas y más o menos agrias. Aquel don Juan Botella era tremendo, todo lo discutía con acritud y mala intención. Galarza tomaba a veces tonos declamatorios y Maura también. Don Niceto y don Paco Largo intimaron mucho sus relaciones de amistad: serios los dos pero simpaticones. Yo pasé una buenísima temporada. Las noches de Navidad y de Fin de Año nos sirvieron dos estupendos banquetes: uno por el Hotel Florida y el otro por Lhardy por cuenta de la Agrupación Socialista de Madrid. De ellos participó el personal de la cárcel: vigilantes e inspectores sobre todo. Nadie se puso enfermo más allá de alguna que otra indigestión y aún de alguno que estuvo con la "poderosa»y no soltó la «cruda» (como se dice en México) hasta el día siguiente.

Parece evidente que en su estancia en la Modelo durante estos dos meses, la situación varió sustancialmente respecto a experiencias pretéritas no sólo por las compañías sino también por el ambiente que se respiraba, de cambio de ciclo político. Y es que tras la caída del dictador, los gobiernos del general Dámaso Berenguer y del almirante Juan Bautista Aznar se esforzaron por mantener la monarquía y el sistema político de la Restauración, pero los tiempos eran otros y la población, especialmente en las ciudades, se echaba a la calle para expresar sus protestas $\mathrm{y}$, sobre todo, para impulsar un cambio de régimen.

De ello eran conocedores los encarcelados y esa atmósfera les hacía más llevadera su falta de libertad. Además no les faltaban muestras de apoyo desde la calle. La referencia en el testimonio anterior al elevado número de visitantes que iba a la prisión a verlos, llevarles viandas y mostrarles su apoyo es suficientemente ilustrativa en ese sentido. A su vez ese ambiente relajado que disfrutaban en la cárcel constituye una muestra de las buenas sensaciones que experimentaba el colectivo de presos políticos, que les hacían augurar cambios futuros esperanzadores. La «marea republicana» se apreciaba en el ambiente y ello colmaba sus aspiraciones.

Situación de espera que no evitó, empero, que la justicia militar les abriera un proceso para depurar sus responsabilidades en relación con los hechos que habían originado su detención. A ese respecto afirma Giral: «nos formó causa el Consejo Superior de Guerra y Marina e hizo el sumario el general jurídico de la Armada, García Patiño, a quien luego tuve a mis órdenes cuando fui ministro de Marina. Preguntaban por el manifiesto que días antes habían hecho los de la Junta Revolucionaria. Yo no pertenecí a ella pero estaba próximo».

Procedimiento que no se prolongó en el tiempo, pues como ya hemos indicado Giral permaneció recluido en el centro penitenciario apenas dos meses. Una vez en libertad, lejos de cejar en su empeño continuó con sus actividades 
clandestinas contra la monarquía. En este sentido es preciso destacar sus labores de enlace con los que estaban escondidos en diferentes inmuebles de Madrid. Conocía su escondite y no dudó en contactar con ellos y mantenerles informados de los acontecimientos.

Me soltaron pronto y en libertad era el contacto con los que estaban ocultos. Lerroux en casa de un escultor italiano que vivía en la calle de la Flora, 2, tabique por medio de la vivienda de Serrano Batanero que no se enteró nunca de su vecino. Marcelino Domingo (se hacía llamar don Sebastián) en casa de Castro Tiedra, redactor jefe del diario «La Libertad». Azaña cambió mucho de escondite pero en donde más estuvo fue en casa del mexicano Martín Luis Guzmán, en la calle Serrano. A Guzmán le llamábamos «El Generalito». Indalecio Prieto, Diego Martínez Barrio y Nicolau se habían ocultado fuera de Madrid. A finales de febrero de 1931, por la noche, tuvimos una reunión en casa de Dámaso Vélez (abogado y gran amigo de Lerroux), en la Plaza de la Villa número uno. Asistimos: Alejandro Lerroux, el citado Vélez, Marcelino Domingo, el general Sanjurjo y yo. Se conspiró lo que se pudo y el «generalote Sanjurjo» se puso a nuestra disposición. Me parece que entonces era Director General de la Guardia Civil».

Su comunicación, por tanto, con los principales líderes de la oposición monárquica continuaron tras su puesta en libertad. Conocía su paradero y la predisposición a establecer puentes entre ellos fue una constante. $\mathrm{Y}$ es que para entonces el sistema de partidos republicanos aumentó con celeridad y los socialistas se unificaban y fortalecían. Contexto en que llama la atención que a esas reuniones asistiera un protagonista de excepción: el general Sanjurjo ${ }^{64}$, director entonces de la Guardia Civil, al que no importó establecer relación con ellos. Contactos sobre los que Giral facilita la siguiente información:

A mediados de febrero de 1931 (cuando aún permanecía en la cárcel la mayor parte del Comité Revolucionario y yo ya disfrutaba de libertad) tuvo lugar una reunión secreta en casa de Dámaso Vélez (Plaza de la Villa), que era el abogado de Alejandro Lerroux, a la que asistimos el general Sanjurjo, Marcelino Domingo, que salió de su escondite en la casa de Castro Tiedra, Redactor-Jefe de «La Libertad», y yo. Sanjurjo estaba dispuesto a ayudarnos. Incluso el 14 de abril de ese año, es decir el día que se proclamó la Segunda República, visité el domicilio del recién nombrado ministro de Gobernación del republicano Gobierno provisional, Miguel Maura, y allí estaba el general, que había ido a ofrecerse a la naciente República y a recibir instrucciones para la salida de Madrid del Rey y de su familia.

Comportamiento de Sanjurjo que dista mucho de lo que sería su conducta tras el advenimiento de la Segunda República, en la que el «generalote» se convirtió en uno de sus principales detractores. Por su parte los apoyos socia-

64 SACANELL RUIZ DE APODACA, 2004. 
les al rey Alfonso XIII decrecieron considerablemente y las organizaciones políticas afines mostraban evidente desorganización. Se imponía una convocatoria electoral y se optó, en primer lugar, por unos comicios municipales antes que generales. Se fijaron para el 12 de abril de 1931. Un mes que celebraba en sus primeros días la tradicional Semana Santa, una festividad que la familia Giral pasó en la hospedería del monasterio cacereño de Guadalupe, con anécdota incluida: «yo llevaba el mismo maletín que usé en la cárcel y aún tenía la etiqueta celda de políticos, letra $H$. Lo vieron los inocentes frailecitos y el Prior me interrogó suavemente y sonriéndose: la República se mascaba ya».

Y no andaba desencaminado Giral en sus apreciaciones, pues el resultado de las elecciones municipales dieron la victoria a la coalición de republicanos y socialistas en las grandes ciudades españolas, mientras que los monárquicos y conservadores ganaron en las zonas rurales. Ante esa situación el Comité Revolucionario, presidido por Niceto Alcalá Zamora, aprovechó para dar un ultimátum que monarca y gobierno, contrarios a todo recurso a la violencia, aceptan. El rey decide suspender el ejercicio del poder real y deja paso a la república, marchándose de España. El 14 de abril, referido Comité se constituye en gobierno provisional y se proclama la Segunda República española ante una población que aclama la llegada del nuevo régimen.

Para muchos, entre ellos nuestro protagonista, esta jornada vieron cumplidos sus sueños. Las reivindicaciones de tantos años por un cambio de sistema político en el país, que a Giral le habían supuesto, entre otras contrariedades, pasar por prisión en varias ocasiones, se veían ahora debidamente cumplidas. Se abría un nuevo horizonte lleno de esperanza e ilusión en toda España, con importantes retos que los dirigentes republicanos debían afrontar sin demora.

Concluimos con este advenimiento del tiempo republicano un trabajo en el que se ha tratado de aportar información novedosa, a través de la documentación inédita procedente del archivo personal de José Giral, sobre los movimientos de oposición a la monarquía durante la etapa dictatorial de Primo de Rivera. Proceso en que se pone de manifiesto que esas actividades, especialmente en la segunda mitad de la década de los veinte, fueron coordinadas por unas fuerzas políticas en la clandestinidad cada vez mejor organizadas en su objetivo de derrocar al régimen. Labor en la que Giral, destacado seguidor de las señas de identidad republicanas, se convirtió en un importante adalid, pese a las contrariedades que ello le originó tanto en su vida profesional como familiar.

\section{Bibliografía}

Alía Miranda, Francisco, Duelo de sables: el General Aguilera de ministro a conspirador contra Primo de Rivera (1917-1931), Madrid, Biblioteca Nueva, 2006. 
Álvarez Rey, Leandro, Bajo fuero militar: la dictadura de Primo de Rivera en sus documentos (1923-1930), Sevilla, Universidad de Sevilla, 2006.

Andrés Gallego, José, El socialismo durante la Dictadura, 1923-1930, Madrid, 1977.

Aroca Mohedano, Manuela, General Hernández Sarabia. El ayudante militar de Azaña, Madrid, Oberón Editorial, 2006.

Ben Amí, Shlomo, La dictadura de Primo de Rivera, 1923-1930, Madrid, Planeta, 1984.

Ben Amí, Shlomo, Los orígenes de la Segunda República española: anatomía de una transición, Madrid, Alianza Editorial, 1990.

Bosch Giral, Pedro, «Giral, paleta del mil colores», en Pedro Bosch Giral et Al., Protagonistas de la química en España: los orígenes de la catálisis, Madrid, Consejo Superior de Investigaciones Científicas, 2010; 187-222.

Buen, Odón de: Mis memorias (Zuera, 1863 - Toulouse, 1939), Zuera (Zaragoza), IFC-Ayuntamiento de Zuera, 2003.

Castañeda, Paloma, Unamuno y las mujeres, Madrid, Editorial Visión Libros, 2008.

Chaves Palacios, Julián: «El republicano José Giral, en Salamanca durante la Restauración (1905-1920)», Investigaciones Históricas 32 (2012); 195-216.

Dardé Morales, Carlos, «Los grupos marginales», en José Andrés-Gallego, Historia General de España y América: Revolución y Restauración (1868-1931), Madrid, Ediciones Rialp, 1981, XVI-2; 130-156.

Egido León, Ángeles, Manuel Azaña entre el mito y la leyenda, Valladolid, Junta de Castilla y León, 1998.

Egido León, Ángeles, «José Giral: Historia de unas memorias», en Ángeles Egido León (ed.), Republicanos en la memoria. Azaña y los suyos, Madrid, Eneida, 2006; 105-122.

El País, 2-VII-1982.

García Delgado, José Luis y Jiménez, Juan Carlos, Un siglo de España: la economía, Madrid, Marcial Pons, 2001.

Gargallo Vaamonde, Luis, El sistema penitenciario de la Segunda República: antes y después de Victoria Kent (1931-1936), Madrid, Ministerio del Interior de España, 2011.

Giral, Francisco. Vida y obra de José Giral Pereira, México, UNAM, 2004.

Giral, Francisco. Ciencia española en el exilio (1939-1989): el exilio de los científicos españoles, Madrid, Anthropos, 1994.

Gómez Navarro, José Luis., El régimen de Primo de Rivera: reyes, dictaduras, y dictadores. Madrid, Cátedra, 1995.

González Calleja, Eduardo, La España de Primo de Rivera: la modernización autoritaria 1923-1930, Madrid, Alianza Editorial, 2005.

González Calleja, Eduardo y Ribagorda Esteban, Álvaro, La Universidad Central durante la II República. Las ciencias humanas y sociales en la vida universitaria (1931-1939), Madrid, Dykinson, 2013.

Jover, José María y Gómez Ferrer, Gonzalo y Fusi, Juan Pablo, España: sociedad, política y civilización (siglos XIX y XX), Madrid, Areté, 2001. 
Jover, José María y Gómez-Ferrer, Gonzalo, «La crisis de la Monarquía Parlamentaria», en José María Jover y otros, España: sociedad, política y civilización (siglos $X I X-X X)$, Madrid, Editorial Debate, 2001; 507-574.

Juliá, Santos, Vida y tiempo de Manuel Azaña, Madrid, Taurus, 2008.

Martorell Linares, Miguel, José Sánchez Guerra. Un hombre de honor (1859-1935), Madrid, Marcial Pons, 2011.

Massot i Muntaner, Josep, Antoni M. Sbert. Agitador, politic i promotor cultural, Barcelona, Publicaciones Abadía de Montserrat, 2000.

Miralles, Ricardo, Juan Negrín. La República en guerra, Madrid, Temas de Hoy, 2003 Moradiellos, Enrique, Don Juan Negrín, Barcelona, Península, 2006.

Otero Carvajal, Luis Enrique, «La depuración de la Universidad de Madrid», en Luis Enrique Otero Carvajal (Dir.), La destrucción de la ciencia en España: depuración universitaria en el franquismo, Madrid, Editorial Complutense, 2006; 123-124.

Otero Carvajal, Luis Enrique, «La destrucción de la ciencia en España. Las consecuencias del triunfo militar en la España franquista», Historia y Comunicación Social, 6, (2001); 149-186.

Perea Capulino, Juan, Los culpables: recuerdos de la guerra (1936-1939), Barcelona, Flor de Viento, 2007

Pérez Galdós, Benito, Revolución de Julio, Buenos Aires, Tecnibook Ediciones, 2011.

Pérez-Rubén, Juan, «Nacimiento y desarrollo de la química oceanográfica española (1911-1931)», Revista Electrónica del Instituto Español de Oceanografía, 7, (enero-marzo 2007); 17-21.

Pozo Andrés, María del Mar, «La Escuela Nueva en España. Crónica y semblanza de un mito», Historia de la Educación: Revista interuniversitaria, 22-23, 20032004; 317-346.

Puerto, Javier, Giral: el domador de tormentas. La sombra de Manuel Azaña, Madrid, Ediciones Corona Borealis, 2003.

Rabaté, Colette y Jean-Claude, Miguel de Unamuno. Biografía, Madrid, Taurus, 2009.

Rivas, Félix y Antoranz, María Antonia (Coord.), Fermín Galán en Biscarrués. La muerte de un hombre, el nacimiento de una leyenda, Biscarrués, Ayuntamiento de Biscarrués, 2011.

Roig Rosich, Josep María, Francesc Maciá: de militar espanyol a independentista catalá (1927-1923), Madrid, La Esfera de los Libros, 2006.

Ruiz Manjón, Octavio, El Partido Republicano Radical, Madrid, Tebas, 1976.

Sacanell Ruiz de Apodaca, Enrique, El general Sanjurjo, héroe y víctima, Madrid, La Esfera de los Libros, 2004.

Salas, Nicolás, Quién fue Gonzalo Queipo de Llano, Sevilla, ABEC, 2012.

Sueiro Seoane, Susana, «El complot catalanista de Prats de Molió: una intriga internacional oculta tras un suceso interno», Espacio, Tiempo y Forma, 5 (1992); 385-396.

Tamames, Ramón, Ni Mussolini ni Franco: la dictadura de Primo de Rivera y su época. Barcelona, Planeta, 2008. 
Tusel, Javier, Radiografía de un golpe de estado. El ascenso al poder del general Primo de Rivera. Madrid, Alianza Editorial, 1987.

Ucelay da Cal, Enric, Francesc Maciá: una vida en imatges, Barcelona, Generalitat de Cataluña, 1984.

Urmeneta, Xavier y Markez, Iñaki, Fernando Sasian Brau, alcalde republicano de San Sebastian: el olvido histórico, San Sebastián, Diputación Foral y Ayuntamiento, 2013.

VV. AA., «Académicos numerarios del Instituto de España (1938-2004)», Instituto de España, Madrid, 2005.

Recibido: $15 / 12 / 2013$

Aceptado: 03/09/2014 